\title{
Vertical partitioning of phosphate uptake among picoplankton groups in the low Pi Mediterranean Sea
}

\author{
A. Talarmin ${ }^{1,2, *}$, F. Van Wambeke ${ }^{1,2}$, P. Lebaron ${ }^{3,4}$, and T. Moutin ${ }^{1,2}$ \\ ${ }^{1}$ Aix Marseille Université, Mediterranean Institute of Oceanography (MIO), 13288, Marseille, CEDEX 9, France \\ ${ }^{2}$ Université de Toulon, 83957, CNRS-INSU/IRD, France \\ ${ }^{3}$ Sorbonne Universités, UPMC Univ. Paris 06, USR 3579, LBBM, Observatoire Océanologique, 66650, Banyuls-sur-Mer, \\ France \\ ${ }^{4}$ CNRS, USR 3579, LBBM, Observatoire Océanologique, 66650 Banyuls-sur-Mer, France \\ * now at: Red Sea Research Center, 4700 King Abdullah University of Science and Technology, Thuwal, 23955-6900, Saudi \\ Arabia
}

Correspondence to: A. Talarmin (agathe.talarmin@gmail.com)

Received: 15 September 2014 - Published in Biogeosciences Discuss.: 13 October 2014

Revised: 2 February 2015 - Accepted: 4 February 2015 - Published: 26 February 2015

\begin{abstract}
Microbial transformations are key processes in marine phosphorus cycling. In this study, we investigated the contribution of phototrophic and heterotrophic groups to phosphate $(\mathrm{Pi})$ uptake fluxes in the euphotic zone of the lowPi Mediterranean Sea and estimated Pi uptake kinetic characteristics. Surface soluble reactive phosphorus (SRP) concentrations were in the range of $6-80 \mathrm{nmol} \mathrm{L}^{-1}$ across the transect, and the community Pi turnover times, assessed using radiolabeled orthophosphate incubations, were longer in the western basin, where the highest bulk and cellular rates were measured. Using live cell sorting, four vertical profiles of $\mathrm{Pi}$ uptake rates were established for heterotrophic prokaryotes (Hprok), phototrophic picoeukaryotes (Pic) and Prochlorococcus (Proc) and Synechococcus (Syn) cyanobacteria. Hprok cells contributed up to $82 \%$ of total Pi uptake fluxes in the superficial euphotic zone, through constantly high abundances $\left(2.7-10.2 \times 10^{5}\right.$ cells $\left.\mathrm{mL}^{-1}\right)$ but variable cellular rates $\left(6.6 \pm 9.3\right.$ amol $\left.\mathrm{P}_{\text {cell }}{ }^{-1} \mathrm{~h}^{-1}\right)$. Cyanobacteria achieved most of the Pi uptake (up to $62 \%$ ) around the deep chlorophyll maximum depth, through high abundances (up to $1.4 \times 10^{5}$ Proc cells $\mathrm{mL}^{-1}$ ) and high cellular uptake rates (up to 40 and 402 amol P cell $^{-1} \mathrm{~h}^{-1}$, respectively for Proc and Syn cells). At saturating concentrations, maximum cellular rates up to 132 amol $\mathrm{P}_{\text {cell }}{ }^{-1} \mathrm{~h}^{-1}$ were measured for Syn at station (St.) C, which was 5 and 60 times higher than Proc and Hprok, respectively. Pi uptake capabilities of the different groups likely contribute to their vertical distribution in the
\end{abstract}

low Pi Mediterranean Sea, possibly along with other energy limitations.

\section{Introduction}

Understanding nutrient uptake strategies in microorganisms is a necessity to predict their biogeochemical response to environmental changes. Heterotrophic (Hprok) and phototrophic prokaryotes (cyanobacteria) dominate the planktonic biomass in oligotrophic areas of the surface ocean and account for most of the carbon fluxes through the microbial loop (Azam et al., 1983). Nanomolar concentrations of orthophosphate $(\mathrm{Pi})$ and $\mathrm{Pi}$ turnover times as low as minutes or hours are seasonally observed in the Sargasso and Mediterranean seas (e.g., McLaughlin et al., 2013; Moutin et al., 2002; Sebastián et al., 2012; Thingstad et al., 1998; Wu et al., 2000). Pi is the preferred form of phosphorus for most osmotrophs, but recent studies show that dissolved organic phosphorus (DOP) can be a significant source of $\mathrm{P}$ as well, particularly in its most labile forms like ATP (e.g., Björkman and Karl, 1994; Björkman et al., 2012; Casey et al., 2009; Duhamel et al., 2012; Fu et al., 2006; Lomas et al., 2010; Sebastián et al., 2012). It is now well established that concentrations of $\mathrm{Pi}$ in the environment impact uptake processes by microbes, who rely on high affinity systems via active transport at low concentrations and high capacity systems and diffu- 
sion at higher environmental Pi concentrations (e.g., Knauss and Porter, 1954; Nyholm, 1977). Along with an increased stratification and oligotrophication of the surface ocean, a widely spread size-shift in the structure of phytoplankton communities is expected, from nano- and micro- eukaryotes to pico-sized cells, as observed in the North Pacific Subtropical Gyre (Church et al., 2002; Karl et al., 2001). How phytoplankton and bacteria share $\mathrm{P}$ resources when they are poorly available has been debated for over 30 years. The existence of different Pi acquisition systems in microorganisms was highlighted in studies where Hprok systems were found to be saturating at much lower Pi concentrations than phototrophic eukaryotes (> $3 \mu \mathrm{m}$ : Currie and Kalff, 1984; Currie et al., 1986). Some eukaryotes possess mixotrophic capabilities: grazing on P-richer prokaryotes (Christaki et al., 1999; Hartmann et al., 2011) as well as DOP hydrolysis induced by ectoenzymes (ATPases, alkaline phosphatases, e.g., Webb, 1992) can fill most of their requirements of P. Eukaryotic phytoplankton may compensate for their low affinity for the substrate at low concentrations (high $\mathrm{Km}$ ) with high Pi storage capacity (Cotner and Biddanda, 2002) compared to prokaryotes and a more efficient growth mechanism, i.e., a low half-saturation constant for growth (Ks, Rhee, 1973). Pi uptake by microbes in natural environments has largely been assessed using size fractionation. Studies concur on the high contribution of the small size fractions $(<0.8,<1,<2$ or $<3 \mu \mathrm{m}$ ) to Pi uptake fluxes (Björkman and Karl, 1994; Currie et al., 1986; Moutin et al., 2002; Tanaka et al., 2003; Thingstad et al., 1993, 1998). This contribution generally increases in aquatic systems with short Pi turnover times and also in low Pi systems after P amendments, emphasizing the idea that heterotrophic prokaryotes are high competitors in P-deficient areas (e.g., Björkman et al., 2012; Currie et al., 1986; Drakare, 2002; Labry et al., 2002). However, size fractionation offers a limited resolution of microbial processes, especially in oligotrophic environments where osmotrophs are small and where taxonomic and functional types overlap in size. The development of combined radiolabeling techniques and cell sorting by flow cytometry has improved the level of resolution for studying Pi uptake strategies in heterotrophic and phototrophic microbes (e.g., Björkman et al., 2012; Casey et al., 2009; Duhamel et al., 2012; Lomas et al., 2014; Talarmin et al., 2011b; Zubkov et al., 2007).

When looking into the contribution of picoplanktonic groups to total Pi uptake, prokaryotes are better competitors than eukaryotes. Among prokaryotes, measured cellular uptake rates of Pi were higher for Synechococcus (Syn) compared to Hprok and Prochlorococcus (Proc) in the Sargasso Sea (Michelou et al., 2011), and higher for Proc compared to Hprok in the North Pacific Subtropical Gyre (Björkman et al., 2012), especially during light incubation (Duhamel et al., 2012). Nevertheless, comparison among those studies is not always possible, due to methodological differences (fixation, inducing Pi leakage) or to different targeted groups. Finally, only one study suggests the adaptation of microorganisms to
P amendments (Björkman et al., 2012), with concentration kinetics experiments providing useful insights into their coexistence in low Pi environments.

The present study investigates the contribution of sorted picoplankton groups to total Pi uptake flux in the low Pi stratified upper water column of the Mediterranean Sea (down to $200 \mathrm{~m}$ ). An estimation of kinetic constants (maximum Pi uptake rate- $V^{\max }$, and the sum of the half-saturation constant plus Pi natural concentration $K+S_{\mathrm{n}}$ ) of ${ }^{33} \mathrm{Pi}$-radiolabeled orthophosphate uptake in sorted Hprok, cyanobacterial and picophytoplanktonic cells is also provided to compare competitive abilities of the groups at different depths and under different ambient Pi concentrations. In spite of the amount of phosphorus-related studies conducted in the Mediterranean Sea, such experiments have never been carried out in this system. Our results contribute to further the understanding of how prokaryotic autotrophs and heterotrophs share scarce resources when the phytoplankton biomass is dominated by prokaryotes.

\section{Material and methods}

\subsection{Study sites and collection}

An east-west transect across the Mediterranean Sea was undertaken during the BOUM cruise (Biogeochemistry from Oligotrophic to Ultraoligotrophic Mediterranean) on the French R/V L'Atalante from 16 June to 20 July 2008 (Fig. 1). Samples were collected using $12 \mathrm{~L}$ Niskin bottles mounted on a rosette equipped with a conductivity, temperature and density (CTD) profiler and sensors for pressure, oxygen, photosynthetically available radiation (PAR) and chlorophyll fluorescence. Pi uptake and turnover time measurements reported in this study were fully processed onboard. Total Chlorophyll $a$ (TChl $a$ ) concentrations were determined as described in Crombet et al. (2011). Critical depths and integrated nutrient concentrations were calculated as described in Moutin and Prieur (2012). Pi turnover times were measured at each of the 30 stations at fixed depths of 5, 25, 50, 75,100 and $125 \mathrm{~m}$. Vertical Pi uptake profiles of Pi uptake in sorted groups at stations 9, 21, A and 25 are presented here, as well as concentration bioassay experiments conducted at stations $\mathrm{C}$ and $\mathrm{A}$.

\subsection{Enumeration of phototrophs and heterotrophs using flow cytometry}

Triplicated aliquots of $1.8 \mathrm{~mL}$ were sampled and fixed with a $2 \%(w / v)$ formaldehyde solution, stored for at least $30 \mathrm{~min}$ at room temperature, flash frozen in liquid nitrogen and then stored at $-80^{\circ} \mathrm{C}$ until further processing onshore within 6 months. Samples were thawed an hour before analysis and $1 \mu \mathrm{m}$ yellow-green beads (Fluoresbrite, Polysciences) were systematically added as a standard. The sheath fluid was filtered $(<0.2 \mu \mathrm{m})$ seawater, and analyses were conducted with 


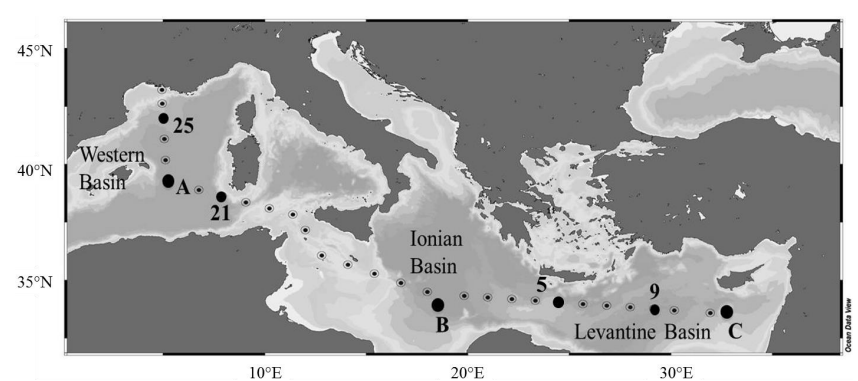

Figure 1. Map of the Mediterranean Sea with locations of sampling sites during the BOUM cruise transect. Numbered and lettered stations denote locations where our experiments were conducted.

the software Cell Quest Pro. Microbes were enumerated using a FACScan flow cytometer (BD Biosciences) equipped with an air-cool argon laser $(488 \mathrm{~nm}, 15 \mathrm{~mW})$. The red fluorescence signal of the Chlorophyll $a$ was collected on a longpass filter $(>650 \mathrm{~nm})$ to identify phytoplankton groups including Prochlorococcus and pico-phytoeukaryotes, according to Marie et al. (2000). Synechococcus cells were distinguished from other phototrophs using their orange fluorescence signal $(585 / 21 \mathrm{~nm})$.

Samples for the enumeration of heterotrophic prokaryotes were stained with SYBRGreen I (Invitrogen-Molecular Probes) at $0.025 \%$ (vol/ vol) final concentration for $15 \mathrm{~min}$ at room temperature in the dark. Counts were performed using a FACSCalibur flow cytometer (BD Biosciences) equipped with an air-cooled argon laser $(488 \mathrm{~nm}, 15 \mathrm{~mW})$. Stained bacterial cells were determined and enumerated according to their right-angle light scatter (SSC) and green fluorescence of the nucleic acid dye $(530 / 30 \mathrm{~nm})$. Autotrophic prokaryotes were discarded from this analysis based on their red fluorescence.

\subsection{Sample preparation for Pi uptake measurements}

Clean $30 \mathrm{~mL}$ polycarbonate Nalgene bottles were filled with $10 \mathrm{~mL}$ of seawater samples. Preliminary measurements were conducted at the beginning of the cruise to adjust the incubation conditions so that Pi uptake was linear with time. The methodology and calculations employed for bulk and cellnormalized, taxon-specific Pi uptake rates were based on the protocol by Talarmin et al. (2011b). In brief, a radioactive working solution was freshly prepared on board by diluting a carrier-free $\left[{ }^{33} \mathrm{P}\right]-\mathrm{H}_{3} \mathrm{PO}_{4}$ mother solution (Perkin Elmer, USA, $569.5 \times 10^{12} \mathrm{~Bq} \mathrm{mmol}^{-1}$ ) in $0.2 \mu \mathrm{m}$-filtered milliQ water, and added to the samples. ${ }^{33} \mathrm{Pi}$ incorporation at room temperature, under natural light condition, was stopped by adding an excess amount $(0.1 \mathrm{mM}$ final concentration) of a cold Pi solution. Samples were split in three aliquots of $5 \mathrm{~mL}$ (for bulk whole-water Pi-uptake measurements), $3.5 \mathrm{~mL}$ (for sorting of phototrophic groups) and $1.5 \mathrm{~mL}$ (for sorting of Hprok cells), and kept in the dark at $4{ }^{\circ} \mathrm{C}$ until further processing $(<1 \mathrm{~h}$ for the $5 \mathrm{~mL}$ subsamples, $10 \mathrm{~min}$ to $6 \mathrm{~h}$ for the others). A cold Pi solution was added to blank samples (final concentration of $\left.0.1 \mathrm{mmol} \mathrm{L}^{-1}\right) 15 \mathrm{~min}$ prior to radiolabeling and processed like other samples. Blank values represented on average $5.0 \%$ to below $13 \%$ of regular values estimated for bulk $(n=11)$ and sorted groups $(n=36)$, respectively. Blank values were systematically subtracted from the counts, in disintegrations per minute $(\mathrm{dpm}) \mathrm{cell}^{-1}$, for the sorted samples. The radioactivity was counted onboard within $5 \mathrm{~h}$ after addition of the scintillation cocktail using a Packard LS 1600 liquid scintillation counter.

\subsubsection{In situ Pi uptake rates}

At stations A, 9, 21 and 25, samples were collected at several depths in order to assess the vertical distribution of the taxonspecific Pi uptake under ambient concentrations of Pi. Samples were spiked with a final concentration of $20 \mathrm{pmol} \mathrm{L}^{-1}$ of the ${ }^{33} \mathrm{P}$-orthophosphate working solution and incubated for $15 \mathrm{~min}$.

\subsubsection{Concentration kinetics of Pi uptake}

Surface experiments carried out between stations B and C led to unsatisfying results where signals were too weak for phototrophic picoeukaryotes (Pic) and unstained Proc cells could not be detected. The upper deep chlorophyll maximum (DCM) depth was then chosen as a biogeochemically consistent level, considering that the depth of the DCM and nutriclines was expected to vary considerably along the transect. Concentration kinetics experiments were conducted at stations $5, \mathrm{~A}, \mathrm{~B}$ and $\mathrm{C}$ by adding increasing quantities of a cold $\mathrm{KH}_{2} \mathrm{PO}_{4}$ solution $(0,4,8,10,15,20,40,60,80$, $100 \mathrm{nmol} \mathrm{L}^{-1}$ added concentration). Samples were spiked with the radioactive working solution $15 \mathrm{~min}$ later, with an activity of $0.34 \mathrm{MBq}$ per sample, i.e., a final radioactive $\mathrm{Pi}$ concentration of $60 \mathrm{pmol} \mathrm{L}^{-1}$, and incubated for $45 \mathrm{~min}$. Bulk Pi uptake rates, bulk Pi turnover times, bulk and taxonspecific kinetic constants $V^{\max }$ (maximum velocity of Pi uptake) and $K+S_{\mathrm{n}}$ ( $K$ being the half-saturation constant and $S_{\mathrm{n}}$ the natural Pi concentration, their sum being determined as the intersection of the plotted line with the $x$ axis) were based on the work of Thingstad et al. (1993). Such estimations were obtained using the linear regression of Pi turnover time vs. added concentrations.

\subsubsection{Bulk Pi uptake measurements}

The $5 \mathrm{~mL}$ aliquots were gently filtered on a $0.2 \mu \mathrm{m}$ polycarbonate membrane superimposing a GF/D filter soaked with a cold Pi solution without rinsing. A $5 \mathrm{~s}$ increase of the vacuum pressure ended the filtration to remove non-incorporated Pi. Filters were then placed in scintillation vials with $5 \mathrm{~mL}$ of Phase Combining System scintillation cocktail (PCS, GE Healthcare). 


\subsubsection{Flow sorting of labeled picoplankton groups}

Other aliquots were processed by flow sorting on an onboard FACSAria cell sorter (BD Biosciences) equipped with two lasers: a $488 \mathrm{~nm}$ (13 mW, Coherent, Sapphire Solid State) and a $633 \mathrm{~nm}(11 \mathrm{~mW}$, JDS Uniphase air-cooled HeNe), using the same detection strategy as for enumeration of phototrophic and heterotrophic cells. The sheath fluid was $0.2 \mu \mathrm{m}$ filtered seawater. The instrument was controlled by a computer equipped with the FACSDiva software set on the fourway sorting $0 / 32 / 0$ purity mode. Re-sorting of sorted samples was conducted randomly to check for the purity of the sorts, which reached $98 \%$. Sorted cells were collected in $2 \mathrm{~mL}$ microcentrifuge tubes where PCS scintillation cocktail was added up to a final volume of $2 \mathrm{~mL}$.

Experiments were replicated on one occasion, and cellular Pi uptake rates varied by less than $4 \%$ in prokaryotic sorts and by $11 \%$ in Pic $(n=4)$. Analytical error associated with cellular uptake rates was about $10 \%$ and error on cell abundances around $5 \%$.

\subsection{Soluble reactive phosphorus (SRP)}

SRP was measured at the nanomolar level according to the Rimmelin and Moutin procedure (Rimmelin and Moutin, 2005), derived from the initial MAGIC method proposed by Karl and Tien (1992), using $250 \mathrm{~mL}$ triplicates per depth. The detection limit of this technique was around $5 \mathrm{nmol} \mathrm{L}^{-1}$.

\subsection{Statistical analyses and data treatment}

Averaged values are reported as mean \pm 1 standard deviation (SD). The Michaelis-Menten equation was used with estimated $V^{\text {max }}$ and $K+S_{\mathrm{n}}$ to fit a Monod curve to the Pi uptake rates measured. They were only shown when a significant correlation between the model and the data was found $(p<0.05)$. Using the turnover time approach to determine kinetic parameters, $V^{\max }$ and $K+S_{\mathrm{n}}$ can always be determined, but only $V^{\max }$ is relevant in samples where $V=V^{\max }$.

Biomass estimations were used to discuss our results, using our cell abundances and cellular P quotas by Bertilsson et al. (2003) and Ho et al. (2003).

\section{Results}

\subsection{Environmental and biological conditions}

A westward shoaling of the DCM (Table 1) and nutricline depths (120 to $50 \mathrm{~m}$ and 200 to $50 \mathrm{~m}$, respectively) was observed along the transect. Total Chlorophyll $a$ concentrations integrated over $150 \mathrm{~m}$ were up to twice as high in the western basin (e.g., station (St.) 25) compared to the Levantine Basin (e.g., St. 9; Table 1), emphasizing the strong oligotrophic state of the eastern waters.
SRP concentrations were in the range of $6-80 \mathrm{nmol} \mathrm{L}^{-1}$, varying with depth and location (Table 1 ). The highest maximum surface values were measured in the western basin (St. 21 and 25), possibly due to incomplete stratification of the water column and the proximity to the Rhone River compared to other stations. However, short Pi turnover times $(0.8$ to $10 \mathrm{~h}$ ) were estimated (Fig. 2), revealing a high turnover of $\mathrm{Pi}$ in microbial communities along the whole transect at surface depths. It is important to point out that the detection limit for SRP measurements was close to the ambient concentrations, hence a potential overestimation of the latter and of Pi uptake rates calculated using $S_{\mathrm{n}}$. This caveat would not affect the main results of the relative capabilities of sorted groups in a given sample to take up $\mathrm{Pi}$, as the same $\mathrm{Pi}$ concentration was multiplied by the turnover rates $\left(\mathrm{h}^{-1}\right)$ of each sorted group or bulk community for a given depth.

\subsection{Enumeration of microbial groups}

Hprok cells were the most abundant group, and varied little over sampled stations and depths, with an average of $3.9 \pm 0.3 \times 10^{5}$ cells $\mathrm{mL}^{-1}(n=24)$, and were in the range of $2.7 \times 10^{5}-10.2 \times 10^{5}$ cells mL $\mathrm{mL}^{-1}$ (Fig. 3). Abundances of Proc cells varied from undetectable levels to $1.4 \times 10^{5}$ cells $\mathrm{mL}^{-1}$. Their pigment signature was too weak to be detected in surface waters without staining; therefore, many experiments are missing data for Proc cells above $50 \mathrm{~m}$. Syn cells were the most abundant at the coastal station 25 $\left(7.7 \times 10^{4}\right.$ cells $\mathrm{mL}^{-1}$ at $\left.40 \mathrm{~m}\right)$ and the least abundant in the deep euphotic zone $\left(130 \mathrm{~m}\right.$ St. A, $0.6 \times 10^{3}$ cells $\mathrm{mL}^{-1}$; Fig. 3). Finally, Pic cells were the most abundant in the western basin, ranged from 230 cells $\mathrm{mL}^{-1}$ up to $0.3 \times 10^{5}$ cells $\mathrm{mL}^{-1}$.

\subsection{Bulk Pi uptake}

Pi uptake rates ranged between 0.03 and $21.6 \mathrm{nmol} \mathrm{PL}^{-1} \mathrm{~h}^{-1}$ and varied by a factor of 10 along the water column at stations with the lower turnover times (9 and 21), while rates could be multiplied by 200 from one depth to the other at St. 25 and A (Fig. 4). No significant correlation was found between Pi uptake rates and SRP concentrations (Fig. S2). In the western basin, SRP concentrations were close to or no more than twice as high as in the eastern basins $\left(17.2 \pm 14.0 \mathrm{nmol} \mathrm{PL} \mathrm{L}^{-1} \mathrm{~h}^{-1}, n=15\right.$, across the sampled depths), but Pi turnover times however could be 300 times higher in the western basin.

\subsection{Taxon-specific Pi uptake}

When all are available, the summed contributions of the four sorted groups to Pi uptake under ambient Pi concentrations represented $83.3 \pm 30 \%$ of the bulk signal $(n=8)$. At the four stations, a higher contribution (up to $82.5 \%$ at St. A; Fig. 4, Table S1 in the Supplement) of Hprok cells was observed, with cellular uptake rates between 0.74 and 
Table 1. Environmental context of the experiments: sampled depth $(\mathrm{m})$, depth of the deep chlorophyll maximum $\left(\mathrm{DCM}_{\mathrm{d}}\right), 0-150 \mathrm{~m}$ integrated Chl $a$ concentrations, SRP concentrations (mean $\pm \mathrm{SD}$ ), and cellular rates of Pi uptake measured in sorted groups Synechococcus (Syn), Prochlorococcus (Proc), picoeukaryotes (Pic) and heterotrophic prokaryotes (Hprok) measured under ambient concentrations. NA: data not available.

\begin{tabular}{|c|c|c|c|c|c|c|c|c|}
\hline \multirow[t]{2}{*}{ Station } & \multirow{2}{*}{$\begin{array}{l}\text { Depth } \\
\text { (m) }\end{array}$} & \multirow{2}{*}{$\begin{array}{l}\mathrm{DCM}_{\mathrm{d}} \\
\text { (m) }\end{array}$} & \multirow{2}{*}{$\begin{array}{l}\text { Chl } a \text { int } \\
\left(\mathrm{mg} \mathrm{C} \mathrm{m}^{-2}\right)\end{array}$} & \multirow[t]{2}{*}[\mathrm{SRP}]{$\left(\mathrm{nmol} \mathrm{L}^{-1}\right)$} & \multicolumn{4}{|c|}{ Cellular Pi uptake rate $\left(\right.$ amol $\left.\mathrm{P}_{\text {cell }}{ }^{-1} \mathrm{~h}^{-1}\right)$} \\
\hline & & & & & Syn & Proc & Pic & Hprok \\
\hline $\mathrm{C}$ & 100 & 108 & 25.10 & $12.8 \pm 6.7$ & 49.8 & 17.5 & NA & 1.2 \\
\hline 9 & 5 & 128 & 16.20 & $20.2 \pm 2.3$ & 58.7 & NA & NA & 27.7 \\
\hline 9 & 50 & & & $17.6 \pm 1.6$ & 14.0 & NA & NA & 0.7 \\
\hline 9 & 75 & & & $12.4 \pm 3.7$ & 17.6 & NA & NA & 7.6 \\
\hline 9 & 105 & & & $23.1 \pm 3.7$ & 41.7 & 35.5 & NA & 7.1 \\
\hline 9 & 120 & & & $13.6 \pm 1.4$ & 46.5 & 39.9 & NA & 13.5 \\
\hline 5 & 50 & 114 & 24.70 & $12.7 \pm 6.7$ & 43.0 & 13.0 & NA & 0.4 \\
\hline $\mathrm{B}$ & 100 & 141 & 21.20 & $8.6 \pm 0.5$ & 24.3 & 20.3 & NA & 36.1 \\
\hline 21 & 5 & 87 & 22.40 & $9.6 \pm 1.9$ & 401.6 & NA & NA & 3.6 \\
\hline 21 & 50 & & & $13.1 \pm 3.6$ & 9.6 & 12.7 & NA & 2.6 \\
\hline 21 & 70 & & & $14.4 \pm 2.0$ & 9.0 & 2.2 & 8.4 & 0.2 \\
\hline 21 & 85 & & & $80.0 \pm 17.6$ & 23.5 & 5.8 & 49.4 & 0.7 \\
\hline A & 6 & 88 & 24.70 & $10.6 \pm 2.8$ & 24.1 & NA & 8.6 & 11.5 \\
\hline A & 13 & & & $5.8 \pm 2.0$ & 10.7 & NA & 4.0 & 5.8 \\
\hline A & 25 & & & $6.3 \pm 1.0$ & 5.8 & NA & 3.3 & 3.2 \\
\hline A & 75 & & & $8.3 \pm 3.9$ & 8.6 & 11.7 & 11.7 & 1.8 \\
\hline A & 90 & & & $8.3 \pm 0.8$ & 13.1 & 9.5 & 33.7 & 0.4 \\
\hline A & 100 & & & $16.4 \pm 1.4$ & 25.1 & 1.6 & 7.9 & 0.1 \\
\hline A & 110 & & & $24.2 \pm 3.4$ & 5.0 & 1.5 & 7.3 & NA \\
\hline A & 130 & & & $20.2 \pm 1.3$ & 5.7 & 3.6 & 3.8 & 0.1 \\
\hline 25 & 5 & 51 & 38.50 & $17.3 \pm 2.3$ & 68.7 & NA & 44.9 & 8.7 \\
\hline 25 & 25 & & & 18.00 & 48.7 & 37.2 & 55.5 & 16.2 \\
\hline 25 & 40 & & & 18.00 & NA & 30.2 & 67.0 & 1.3 \\
\hline 25 & 50 & & & 18.67 & 49.0 & NA & 134.8 & 0.8 \\
\hline 25 & 60 & & & 19.10 & NA & NA & NA & NA \\
\hline
\end{tabular}

27.75 amol P cell ${ }^{-1} \mathrm{~h}^{-1}$ (Table 1) between surface and 25 or $50 \mathrm{~m}$. In the vicinity of the DCM, cyanobacterial cells were the major contributors to bulk signal (up to $72 \%$ at St. A; Fig. 4), which were mostly Proc cells in open sea samples (Fig. 3a, c). Syn cells constituted $53 \%$ of bulk signal at the coastal station (Table S1), where they reached the highest abundance measured during the cruise, while their average contribution over the cruise was $16.3 \pm 14 \%(n=18)$. Differences between cellular mean rates were not significant $(p=0.06)$, due to a high variability across samples for a single group $(\mathrm{CV} \geq 84 \%)$. However, in half of the samples for which both Syn and Pic were sorted, cellular Pi uptake rates were higher in Syn than in Pic cells (Table 1). The biomass of Pic in the bioassay of St. A reached $1.2 \mathrm{nmol} \mathrm{PL}^{-1}$, whereas it was in the range of $15.7-34.4 \mathrm{nmol} \mathrm{PL}^{-1}$ along the profile at St. 25. These were 300 and 25-55 times higher than the biomass of Syn at the respective stations. Proc estimated biomass was of the same order of magnitude as Syn, around $0.3 \mathrm{nmol} \mathrm{PL}{ }^{-1}$, and Hprok biomass was twice lower than Pic. In 22 out of 23 sorts, Hprok specific rates were consistently lower compared to cyanobacteria. Over all experiments, cellular uptake rates were in the range of 2.6402, 3.6-40.0, 8.4-134.8, and 0.05-36.1 amol $\mathrm{Pcell}^{-1} \mathrm{~h}^{-1}$ for Syn, Proc, Pic and Hprok, respectively (Table 1). Over all sampled depths, Pi uptake was dominated by the smallest organisms up to $99 \%(<2 \mu \mathrm{m}$, Fig. S1).

\subsection{Kinetics of the Pi uptake}

Data from St. C and A could only be used to explore kinetic characteristics, while no response to $\mathrm{Pi}$ addition was observed at St. 5 and B. Cellular $\left(V_{\mathrm{c}}^{\max }\right)$ and volumetric $\left(V^{\max }\right)$ rates are reported in Table 2. Signals measured at St. B and C in sorted Pic cells during the isotope dilution experiments did not show any dose response, and therefore no kinetic parameters were estimated. At St. A and C, the highest $V^{\max }$ was obtained for cyanobacterial sorts (Table 2, Fig. 5). Cellular maximum uptake rates $\left(V_{\mathrm{c}}^{\max }\right)$ were found in different rel- 


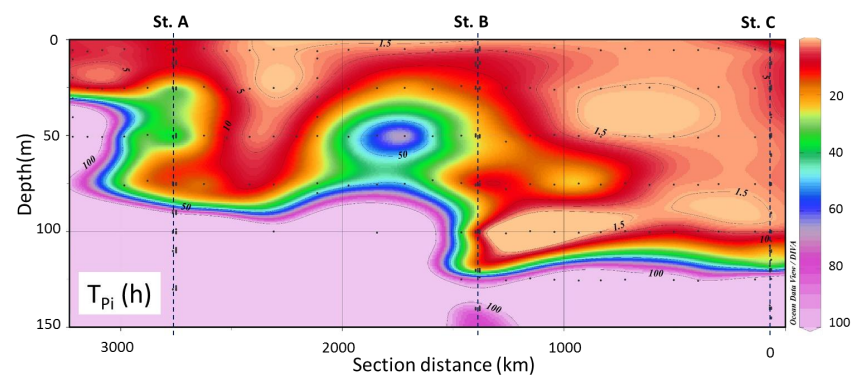

Figure 2. Phosphate turnover time (h) of the bulk community $(>0.2 \mu \mathrm{m})$ over the BOUM cruise transect.

ative orders at both stations, with $V_{\mathrm{c}}^{\max }$ Syn $>$ Proc $>$ Hprok at $\mathrm{St}$. C and Pic $>\mathrm{Syn}>\mathrm{Proc}$ at St. A (Table 2). Estimations of the $K+S_{\mathrm{n}}$ constant Proc and Pic cells at St. A and Syn cells at St. $\mathrm{C}$ were comparable and about 5 times lower than the value measured for Syn cells at St. A $\left(128.4 \mathrm{nmol} \mathrm{PL}^{-1}\right)$. At St. A, Syn, Proc and Pic exhibited a subsaturated Pi uptake under natural conditions (rates measured from profiles compared to $V^{\max }$ at this depth) with 13,44 and $86 \%$, respectively. Both cellular and volumetric maximum rates were drastically lower at St. A compared to St. C, while $K+S_{\text {n }}$ values in the bulk and Syn sorts were higher at St. A.

\section{Discussion}

A recent review on phosphorus marine biogeochemistry pointed out marine microbial cycling of phosphorus as the most dynamic and complex cycle of all (Karl, 2014). With consistently short Pi turnover times $(<10 \mathrm{~h})$ measured in surface samples from the Levantine Basin, congruent with previous studies (Flaten et al., 2005; Moutin et al., 2002), our study emphasizes the short timescale and dynamics of Pi cycling in the Mediterranean. Low Pi turnover times deepening towards the east, while SRP concentrations did not show a clear longitudinal trend and suggest a higher limitation of microbial communities in the Levantine Basin.

\subsection{Taxon-specific Pi uptake}

Cellular Pi uptake rates suggest that there was variability across sorted groups, with Hprok having the lowest rates in most samples. When all three phototrophic groups were successfully sorted, there was not a single group clearly showing higher cellular Pi uptake rates, like there were in samples from the North Atlantic (see, e.g., Pic in Lomas et al., 2014, Syn in Michelou et al., 2011 and Syn and Pic in Zubkov et al., 2007). We measured cellular Pi uptake rates for Proc cells over of 10 -fold higher $\left(16.1 \pm 13.6 \mathrm{amol} \mathrm{P}\right.$ cell $^{-1} \mathrm{~h}^{-1}$, $n=15)$ in the Mediterranean Sea compared to rates measured in the Sargasso Sea $\left(<1 \mathrm{amol} \mathrm{Pcell}{ }^{-1} \mathrm{~h}^{-1}\right.$ : Casey et al., 2009; Michelou et al., 2011; Zubkov et al., 2007). We suggest four main reasons to explain differences across re- gions: (i) different composition of the cyanobacterial community between the Sargasso Sea and the Mediterranean, notably clade HL II which is underrepresented in the Mediterranean (Mella-Flores et al., 2011), (ii) the low proportion of Proc cells $(<10 \%)$ able to utilize Pi in the subsurface layers of the Sargasso Sea (Martínez et al., 2012), (iii) different proportions of live vs. dead cyanobacterial cells in the Sargasso and Mediterranean seas (Agusti, 2004) and (iv) measurements conducted on fixed samples in the mentioned studies from the Sargasso Sea, possibly involving a significant leakage of intracellular Pi (Talarmin et al., 2011b). The dominance of Syn in Pi uptake fluxes above the DCM at St. 25 was likely due to their higher affinity for Pi compared to Pic cells because their biomass was 50 times lower than Pic.

\subsection{Kinetic parameters in sorted groups}

Summed volumetric $V^{\max }$ of sorted groups added up to the community $V^{\max }$ or below. Non-sorted large protists may have higher maximum Pi uptake rates per cell (Casey et al., 2009) or the ability to store large amounts of Pi in case of upwelled or deposited inputs. The kinetic experiment results presented here should be interpreted very cautiously due to their scarcity, and they should serve as a starting point for inferring Pi uptake strategies with regard to environmental conditions. At station $\mathrm{C}$, the groups expected to have a higher affinity for low concentrations did not show a response to $\mathrm{Pi}$ additions because they were taking up $\mathrm{Pi}$ at maximum velocity. Synechococcus was described as a group able to respond rapidly and significantly to pulsed Pi events (Moutin et al., 2002), which could be supported by the fact that Pi uptake under ambient SRP concentrations was not saturated at St. $\mathrm{A}$ or $\mathrm{C}$ and that they did show a response to Pi additions at both stations. Our data also suggest that microbial communities have the potential to take up more Pi when Pi turnover times are short. Per cell Pi uptake rates converted into per volume Pi uptake rates show opposite trends, with cyanobacteria harvesting Pi more efficiently than larger phytoplankton (Casey et al., 2009). With their high surface-to-volume ratio (Azam et al., 1983), prokaryotes with a biovolume below $40 \mu \mathrm{m}^{3}$ may not be constrained by the theoretical surfacelimited growth rate, due to a poor cellular machinery compared to the absorbing capability (Dao, 2013), hence their higher cellular uptake rates under low concentrations compared to picoeukaryotes.

\subsection{Contribution of the sorted groups to total Pi uptake}

Biogeochemically, using volumetric Pi uptake rates is more valuable than the cellular values for highlighting the overall contribution of one group to $\mathrm{Pi}$ fluxes throughout the marine microbial $\mathrm{P}$ cycle. Down to about $25 \mathrm{~m}$ above the DCM, at the four stations sampled for depth profiles, the main contributors to Pi uptake fluxes were the heterotrophic prokaryotes. Michelou et al. (2011) found dominance of bulk 


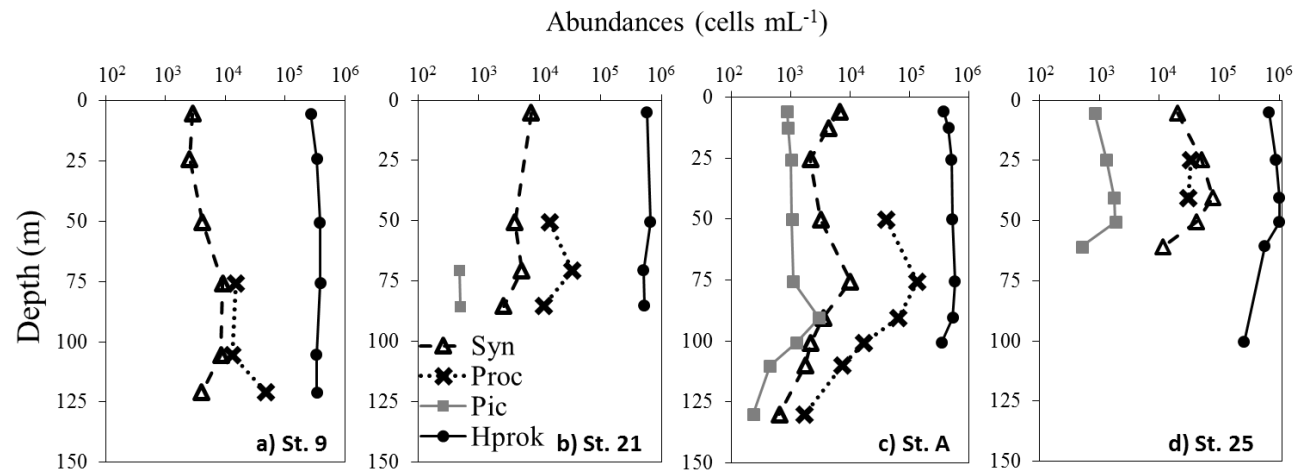

Figure 3. Abundances of Synechococcus (Syn), Prochlorococcus (Proc), picophytoeukaryotes (Pic) and heterotrophic prokaryotes (Hprok) at the depths of sorted experiments at stations $9,21, \mathrm{~A}$ and 25.

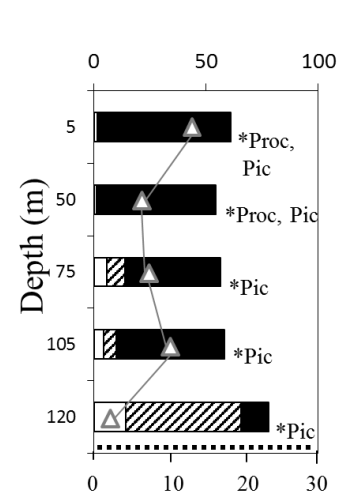

a) St. 9

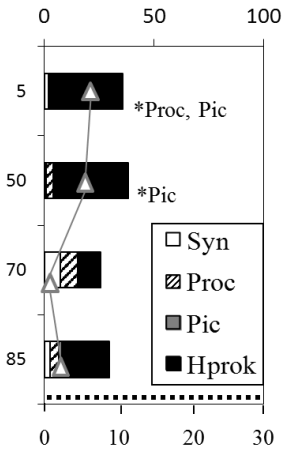

b) St. 21

Contribution to bulk $\mathrm{P}_{\mathrm{i}}$ uptake $(\%)$

$$
\triangle \quad \text { Bulk } \mathrm{P}_{\mathrm{i}} \text { uptake rate }\left(\mathrm{nmol} \mathrm{L}^{-1} \mathrm{~h}^{-1}\right)
$$

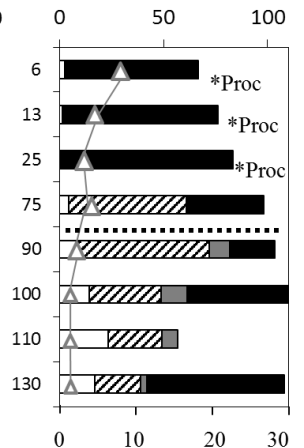

c) St. A

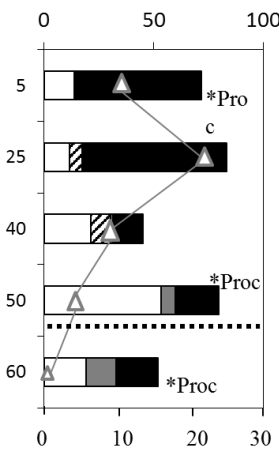

d) St. 25

Figure 4. Cumulated contributions of picoplankton groups (superimposed bars for Synechococcus, Syn; Prochlorococcus, Proc; picophytoeukaryotes, Pic; heterotrophic prokaryotes, Hprok) to the bulk Pi uptake (upper scale, $100 \%=$ measured bulk Pi uptake rate) and bulk Pi uptake rates (lower scale, white triangles) along the euphotic water column at stations 9, 21, A and 25. Dotted horizontal lines mark the deep chlorophyll maximum depth. Please note the different vertical scales. Missing groups are specified with an asterisk (*).

Pi uptake by Hprok in the Sargasso Sea, in surface and DCM layers. These authors determined that cyanobacteria (Proc + Syn) contributed less than $10 \%$ of the Pi uptake fluxes. These contributions were a result of (i) low Syn abundances, although this group exhibited 2- to 5-fold higher cellular uptake rates than Proc and Hprok and intermediate Proc abundances, combined with (ii) lower cellular rates for Proc $\left(0.4\right.$ amol P cell $\left.{ }^{-1} \mathrm{~h}^{-1}\right)$. In contrast, in the Mediterranean Sea we found a higher contribution of cyanobacteria close to the DCM compared to upper layers, mostly due to abundances higher than those observed in the North Atlantic at the time of the cruise (Michelou et al., 2011).

The companion paper of these experiments published earlier by Casey et al. (2009) found no clear difference in the contribution of Proc and Syn to Pi utilization. Proc contributed $45 \%$ of the bulk Pi uptake in the North Atlantic (Zubkov et al., 2007), which is within the range of our measurements $(<L D-62.9 \%)$. In the North Pacific Subtropi- cal Gyre, Pro and Hprok cells did not reveal different contributions to total Pi uptake fluxes, despite taxon-specific rates 3-fold higher for Proc than for Hprok (Björkman et al., 2012). At the SOLA station in the eastern Mediterranean Sea (Banyuls-sur-Mer, France), Syn contributed the most to the total Pi uptake $(35 \%)$ among three sorted groups, while Pic and Hprok showed low and non-significantly different contributions (Talarmin et al., 2011b). For the first time, our results suggest that the uptake of $\mathrm{Pi}$ at an offshore oligotrophic location was not dominated by a single group of microbes in the upper euphotic zone. The present study together with a previously published survey conducted during the same cruise on leucine incorporation in sorted groups (Talarmin et al., 2011a) showed the importance of Prochlorococcus cells in elemental fluxes in the Mediterranean Sea, as it was previously demonstrated in the Sargasso Sea (Casey et al., 2007).

The unexplained fraction in the contribution profiles could be attributed to missing sorts or taxonomic groups that were 
Table 2. Pi uptake kinetic characteristics of the bulk community and sorted groups: $V^{\max }$ is the theoretical volumetric maximum uptake rate of a group, $V_{\mathrm{c}}^{\max }$ is the cellular maximum uptake rate, and $K+S_{\mathrm{n}}$ is the theoretical sum of the half saturation constant for uptake and the natural [Pi]. LD: below the limit of detection ( $<3$ blank values). NA: data not available.

\begin{tabular}{|c|c|c|c|c|c|c|c|c|c|c|c|c|c|c|c|c|}
\hline \multirow[b]{2}{*}{ St. } & \multirow[b]{2}{*}{$z(\mathrm{~m})$} & \multirow[b]{2}{*}{$T_{\mathrm{Pi}}(\mathrm{h})$} & \multicolumn{4}{|c|}{$V_{\mathrm{c}}^{\max }\left(\operatorname{amol~Pcell}{ }^{-1} \mathrm{~h}^{-1}\right)$} & \multicolumn{5}{|c|}{$V^{\max }\left(\mathrm{nmol} \mathrm{PL}^{-1} \mathrm{~h}^{-1}\right)$} & \multicolumn{5}{|c|}{$K+S_{\mathrm{n}}\left(\mathrm{nmol} \mathrm{PL}^{-1}\right)$} \\
\hline & & & Syn & Proc & Pic & Hprok & Bulk & Syn & Proc & Pic & Hprok & Bulk & Syn & Proc & Pic & Hprok \\
\hline $\mathrm{C}$ & 100 & 3.9 & 132 & 21 & LD & 2 & 4.0 & 1.8 & 1.1 & LD & 0.6 & 15.3 & 22.9 & NA & LD & NA \\
\hline A & 90 & 370.9 & 12 & 1 & 99 & NA & 0.2 & 0.03 & 0.02 & 0.02 & NA & 62.6 & 128.4 & 22.7 & 27.7 & NA \\
\hline
\end{tabular}
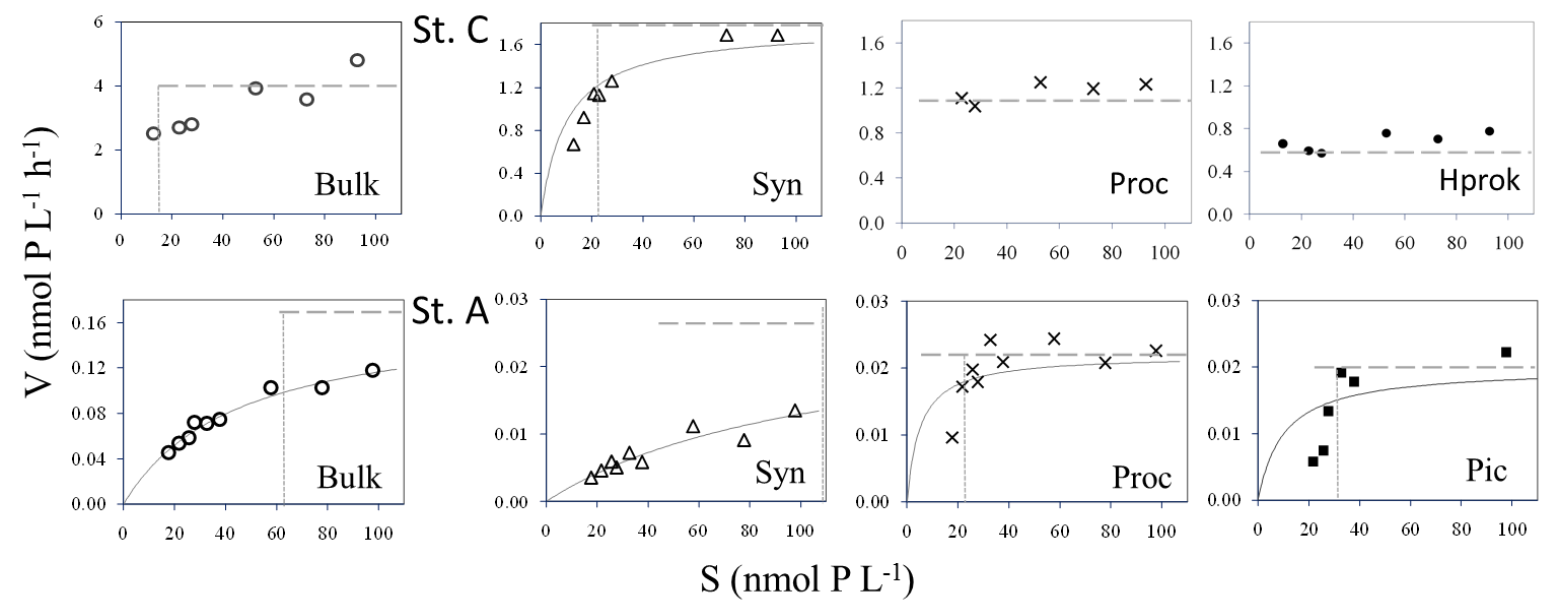

Figure 5. Bulk and taxon-specific Pi uptake rates $(V)$ at increasing Pi concentrations (in situ + added) in sorted Synechococcus (Syn), Prochlorococcus (Proc), picophytoeukaryotes (Pic) and heterotrophic prokaryotes (Hprok) at St. A and C. Straight horizontal and vertical lines represent computed $V^{\max }$ and $K+S_{\mathrm{n}}$, respectively. If a significant correlation $(p<0.05)$ between measured Pi uptake rates and those calculated from the Michaelis-Menten model occurred, the uptake curve was fitted to the data.

not taken into account. For instance, viruses and bacterivorous mixotrophic ciliates or nanoflagellates, which bypass nutrients to the highest trophic levels of the microbial loop by grazing (Krom et al., 2005; Paffenhöfer et al., 2007), or attached bacteria, could also contribute to bulk Pi uptake fluxes. In freshwater systems, they could take up Pi and amino acids at higher rates than free-living bacteria (Paerl and Merkel, 1982; Simon, 1985). Finally, we also considered the possibility that Proc cells from surface layers had toolow Chlorophyll $a$ content to be distinguished from Hprok in stained samples, resulting in an overestimation of the Hprok contribution to bulk Pi uptake in the surface samples where Proc cells were not detected.

\subsection{Other limitations}

The vertical partitioning of Pi uptake observed in the present study suggested that different nutrient uptake strategies and capabilities may contribute to the explanation of the vertical structure of microbial communities throughout the water column. In the surface where SRP concentrations are the lowest, only organisms with the lowest $K+S_{\mathrm{n}}$ can utilize Pi efficiently, i.e., Proc and Hprok cells. The cyanobacterial contribution to Pi uptake possibly decreased below the DCM because of light limitation (Duhamel et al., 2012). During this cruise, a mesocosm study showed that surface communities were submitted to $\mathrm{N}$ and $\mathrm{P}$ co-limitation or $\mathrm{N}$ limitation, but no strict P-limitation (Tanaka et al., 2011), and no nutrient (N, P) limitation was found at St. A. Eighty-nine percent of dust deposition was found to be from anthropogenic sources at this station (Ternon et al., 2011), which may provide more or different $\mathrm{P}$ sources than in the more eastern basins isolated from all inputs. A larger effort in measuring environmental data, combined with phylogenetic analyses of the sorted groups would help to further link the diversity of microbes to their Pi uptake performances. Such experiments have been conducted in mesocosm conditions and showed that different bacterial taxa responded to Pi additions with different strategies in the Mediterranean Sea (Sebastián et al., 2012). The concept of competition among microbes for a limited resource in natural environments is challenged by the numerous potential sources of growth limitation and the high diversity of cytometric groups (e.g., Kashtan et al., 2014; Marie et al., 2010). 


\section{Conclusions}

While a few taxon-specific Pi uptake rates from various areas have been published in the past 7 years, our study was the first to focus on the Mediterranean Sea and uncovering a vertical partition of Pi uptake fluxes among microbial groups. Each group studied in this survey seemed to have a key role in Pi cycling under given environmental conditions, whether through high affinity for $\mathrm{Pi}$ at low concentrations (Hprok and Proc) or the ability to take up Pi at high rates (Syn and Pic) at some depths. The variability observed within and across sorted groups seems to reflect different kinetic abilities ranging along a continuum of Pi uptake strategies as well as phylogenetic diversity within cytometric groups.

We found that different groups dominated bulk Pi uptake fluxes at different depths, with Hprok contributing the most in the surface, subsurface layers and likely also the bottom layers of the euphotic zone, while cyanobacteria dominated fluxes around the DCM zone. Multiple nutrient and energy limitations need to be further investigated to better understand this vertical partition of Pi uptake in oligotrophic waters.

\section{The Supplement related to this article is available online at doi:10.5194/bg-12-1237-2015-supplement.}

Acknowledgements. The authors would like to thank the captain and crew of the R/V L'Atalante, Veronique Cornet for the nanomolar SRP data, Laetitia Bariat and Philippe Catala for providing part of the phytoplankton and bacterial counts, respectively, Anna Lagaria, Stella Psarra and Josephine Ras for Chl $a$ data, Romain Mauriac for the joint effort on turnover time measurements and all the scientists who participated in the BOUM cruise. We acknowledge the crucial contribution of Claude Courties who sorted all the samples on board. Finally, we address our gratitude to the three anonymous reviewers who allowed us to greatly improve this manuscript and highlighted elements that needed clarification and further detailing.

This work is a contribution of the BOUM project (Biogeochemistry from the Oligotrophic to Ultraoligotrophic Mediterranean, http://www.com.univ-mrs.fr/BOUM). It was funded by the French national CNRS-INSU (LEFE-CYBER) program and the European IP SESAME (Southern European Seas: Assessing and Modelling Ecosystem Changes), EC contract no. GOCE-036949. We acknowledge the French Research and Education Council for the funding of A. Talarmin's PhD training.

Edited by: K. Suzuki

\section{References}

Agusti, S.: Viability and niche segregation of Prochlorococcus and Synechococcus cells across the Central Atlantic Ocean, Aquat. Microb. Ecol., 36, 53-59, 2004.

Azam, F., Fenchel, T., Field, J. G., Gray, J. S., Meyer-Reil, L. A., and Thingstad, F.: The Ecological Role of Water-Column Microbes in the Sea, Mar. Ecol.-Prog. Ser., 10, 257-263, 1983.

Bertilsson, S., Berglund, O., Karl, D. M., and Chisholm, S. W. Elemental Composition of Marine Prochlorococcus and Synechococcus: implications for the Ecological Stoichiometry of the Sea, Limnol. Oceanogr., 48, 1721-1731, 2003.

Björkman, K. and Karl, D. M.: Bioavailability of inorganic and organic phosphorus compounds to natural assemblages of microorganisms in Hawaiian coastal waters, Mar. Ecol.-Prog. Ser., 111, 265-273, 1994.

Björkman, K., Duhamel, S., and Karl, D. M.: Microbial Group Specific Uptake Kinetics of Inorganic Phosphate and Adenosine-5 Triphosphate (ATP) in the North Pacific Subtropical Gyre, Frontiers in Microbiology, 3, 189, doi:10.3389/fmicb.2012.00189, 2012.

Casey, J. R., Lomas, M. W., Mandecki, J., and Walker, D. E.: Prochlorococcus contributes to new production in the Sargasso Sea deep chlorophyll maximum Geophys. Res. Lett., 34 L10604, doi:10.1029/2006GL028725, 2007.

Casey, J. R., Lomas, M. W., Michelou, V. K., Dyhrman, S. T., Orchard, E. D., Ammerman, J. W., and Sylvan, J. B.: Phytoplankton taxon-specific orthophosphate $(\mathrm{Pi})$ and ATP utilization in the western subtropical North Atlantic, Aquat. Microb. Ecol., 58, 31-44, doi:10.3354/ame01348, 2009.

Christaki, U., Van Wambeke, F., and Dolan, J. R.: Nanoflagellates (mixotrophs, heterotrophs and autotrophs) in the oligotrophic eastern Mediterranean: standing stocks, bacterivory and relationships with bacterial production, Mar. Ecol.-Prog. Ser., 181, $297-$ 307, 1999.

Church, M. J., Ducklow, H., and Karl, D. M.: Multiyear increases in dissolved organic matter inventories at Station ALOHA in the North Pacific Subtropical Gyre, Limnol. Oceanogr., 47, 1-10, 2002.

Cotner, J. B. and Biddanda, B. A.: Small Players, Large Role: Microbial Influence on Biogeochemical Processes in Pelagic Aquatic Ecosystems, Ecosystems, 5, 105-121, 2002.

Crombet, Y., Leblanc, K., Quéguiner, B., Moutin, T., Rimmelin, P., Ras, J., Claustre, H., Leblond, N., Oriol, L., and Pujo-Pay, M.: Deep silicon maxima in the stratified oligotrophic Mediterranean Sea, Biogeosciences, 8, 459-475, doi:10.5194/bg-8-4592011, 2011.

Currie, D. J. and Kalff, J.: A comparison of the abilities of freshwater algae and bacteria to acquire and retain phosphorus, Limnol. Oceanogr., 29, 298-310, 1984.

Currie, D. J., Bentzen, E., and Kalff, J.: Does algal-bacterial phosphorus partitioning vary among lakes? a comparative study of orthophosphate uptake and alkaline phosphatase activity in freshwater, Can. J. Fish. Aquat. Sci., 43, 311-318, doi:10.1139/f86040, 1986.

Dao, M. H.: Reassessment of the cell surface area limitation to nutrient uptake in phytoplankton, Mar. Ecol. Prog. Ser., 489, 87-92, doi:10.3354/meps10434, 2013.

Drakare, S.: Competition between Picoplanktonic Cyanobacteria and Heterotrophic Bacteria along Crossed Gradients 
of Glucose and Phosphate, Microbial Ecol., 44, 327-335, doi:10.1007/s00248-002-1013-4, 2002.

Duhamel, S., Björkman, K. M., and Karl, D. M.: Light dependence of phosphorus uptake by microorganisms in the subtropical North and South Pacific Ocean, Aquat. Microb. Ecol., 67, 225-238, doi:10.3354/ame01593, 2012.

Flaten, G. A. F., Skjoldal, E. F., Krom, M. D., Law, C. S., Mantoura, R. F. C., Paraskevi, P., Psarra, S., Tanaka, T., Tselepides, A., Woodward, E. M. S., Zohary, T., and Thingstad, T. F.: Studies of the microbial P-cycle during a Lagrangian phosphate-addition experiment in the Eastern Mediterranean, Deep Sea Res. Pt. II, 52, 2928-2943, 2005.

Fu, F. X., Zhang, Y., Feng, Y., and Hutchins, D. A.: Phosphate and ATP uptake and growth kinetics in axenic cultures of the cyanobacterium Synechococcus CCMP 1334, Eur. J. Phycol., 41, 15-28, 2006.

Hartmann, M., Grob, C., Scanlan, D. J., Martin, A. P., Burkill, P. H., and Zubkov, M. V.: Comparison of phosphate uptake rates by the smallest plastidic and aplastidic protists in the North Atlantic subtropical gyre, FEMS Microbiol. Ecol., 78, 327-335, doi:10.1111/j.1574-6941.2011.01160.x, 2011.

Ho, T.-Y., Quigg, A., Finkel, Z. V., Milligan, A. J., Wyman, K., Falkowski, P. G., and Morel, F. M. M.: The elemental composition of some marine phytoplankton, J. Phycol., 39, 1145-1159, doi:10.1111/j.0022-3646.2003.03-090.x, 2003.

Karl, D. M.: Microbially Mediated Transformations of Phosphorus in the Sea: New Views of an Old Cycle, Annual Review of Marine Science, 6, 279-337, doi:10.1146/annurev-marine-010213135046, 2014.

Karl, D. M. and Tien, G.: MAGIC: A sensitive and precise method for measuring dissolved phosphorus in aquatic environments, Limnol. Oceanogr., 37, 105-116, 1992.

Karl, D. M., Bidigare, R. R., and Letelier, R. M.: Long-term changes in plankton community structure and productivity in the North Pacific Subtropical Gyre: The domain shift hypothesis, Deep Sea Res. Pt. II, 48, 1449-1470, doi:10.1016/S0967-0645(00)001491, 2001.

Kashtan, N., Roggensack, S., Rodrigue, S., Thompson, J. W., Biller, S. J., Coe, A., DIng, H., Marttinen, P., Malmstrom, R. R., Stocker, R., Follows, M. J., Stepanauskas, R., and Chisholm, S. W.: Single-cell genomics reveals hundreds of coexisting subpopulations in wild Prochlorococcus, Science, 344, 416-420, doi:10.1126/science.1248575, 2014.

Knauss, H. J. and Porter, J. W.: The absorption of inorganic ions by Chlorella pyrenoidosa, Plant Physiol., 29, 229-234, 1954.

Krom, M. D., Woodward, E. M. S., Herut, B., Kress, N., Carbo, P., Mantoura, R. F. C., Spyres, G., Thingstad, T. F., Wassmann, P., Wexels-Riser, C., Kitidis, V., Law, C. S., and Zodiatis, G.: Nutrient cycling in the south east Levantine basin of the eastern Mediterranean: Results from a phosphorus starved system, Deep Sea Res. Pt. II, 52, 2879-2896, 2005.

Labry, C., Herbland, A., and Delmas, D.: The role of phosphorus on planktonic production of the Gironde plume waters in the Bay of Biscay, J. Plankton Res., 24, 97-117, doi:10.1093/plankt/24.2.97, 2002.

Lomas, M. W., Burke, A. L., Lomas, D. A., Bell, D. W., Shen, C., Dyhrman, S. T., and Ammerman, J. W.: Sargasso Sea phosphorus biogeochemistry: an important role for dissolved organic phos- phorus (DOP), Biogeosciences, 7, 695-710, doi:10.5194/bg-7695-2010, 2010.

Lomas, M. W., Bonachela, J. A., Levin, S. A., and Martiny, A. C.: Impact of ocean phytoplankton diversity on phosphate uptake, $\mathrm{P}$. Natl. A. Sci., 111, 17540-17545, doi:10.1073/pnas.1420760111, 2014.

Marie, D., Simon, N., Guillou, L., Partensky, F., and Vaulot, D.: DNA/RNA Analysis of Phytoplankton by Flow Cytometry UNIT 11.12, Current Protocols in Cytometry, 2000.

Marie, D., Shi, X. L., Rigaut-Jalabert, F., and Vaulot, D.: Use of flow cytometric sorting to better assess the diversity of small photosynthetic eukaryotes in the English Channel, FEMS Microbiol. Ecol., 72, 165-178, doi:10.1111/j.15746941.2010.00842.x, 2010.

Martínez, A., Osburne, M. S., Sharma, A. K., DeLong, E. F., and Chisholm, S. W.: Phosphite utilization by the marine picocyanobacterium Prochlorococcus MIT9301, Environ. Microbiol., 14, 1363-1377, doi:10.1111/j.1462-2920.2011.02612.x, 2012.

McLaughlin, K., Sohm, J. A., Cutter, G. A., Lomas, M. W., and Paytan, A.: Phosphorus cycling in the Sargasso Sea: Investigation using the oxygen isotopic composition of phosphate, enzymelabeled fluorescence, and turnover times, Global Biogeochem. Cy., 27, 375-387, doi:10.1002/gbc.20037, 2013.

Mella-Flores, D., Mazard, S., Humily, F., Partensky, F., Mahé, F., Bariat, L., Courties, C., Marie, D., Ras, J., Mauriac, R., Jeanthon, C., Mahdi Bendif, E., Ostrowski, M., Scanlan, D. J., and Garczarek, L.: Is the distribution of Prochlorococcus and Synechococcus ecotypes in the Mediterranean Sea affected by global warming?, Biogeosciences, 8, 2785-2804, doi:10.5194/bg-82785-2011, 2011.

Michelou, V. K., Lomas, M. W., and Kirchman, D. L.: Phosphate and adenosine-5' -triphosphate uptake by cyanobacteria and heterotrophic bacteria in the Sargasso Sea, Limnol. Oceanogr., 56, 323-332, 2011.

Moutin, T. and Prieur, L.: Influence of anticyclonic eddies on the Biogeochemistry from the Oligotrophic to the Ultraoligotrophic Mediterranean (BOUM cruise), Biogeosciences, 9, 3827-3855, doi:10.5194/bg-9-3827-2012, 2012.

Moutin, T., Thingstad, T. F., Van Wambeke, F., Marie, D., Slawyk, G., Raimbault, P., and Claustre, H.: Does Competition for Nanomolar Phosphate Supply Explain the Predominance of the Cyanobacterium Synechococcus?, Limnol. Oceanogr., 47, 15621567, 2002.

Nyholm, N.: Kinetics of phosphate limited algal growth, Biotechnol. Bioeng., 19, 467-492, doi:10.1002/bit.260190404, 1977.

Paerl, H. and Merkel, S.: The effects of particles on phosphorus assimilation in attached vs. free floating microorganisms, Arch. Hydrobiol, 93, 125-134, 1982.

Paffenhöfer, G. A., Sherr, B. F., and Sherr, E. B.: From small scales to the big picture: persistence mechanisms of planktonic grazers in the oligotrophic ocean, Mar. Ecol., 28, 243-253, 2007.

Rhee, G. Y.: A continuous culture study of phosphate uptake, growth rate and polyphosphate in Scenedesmus sp., J. Phycol., 9, 495-506, doi:10.1111/j.1529-8817.1973.tb04126.x, 1973.

Rimmelin, P. and Moutin, T.: Re-examination of the MAGIC method to determine low orthophosphate concentration in seawater, Anal. Chim. Acta, 548, 174-182, 2005. 
Sebastián, M., Pitta, P., González, J. M., Thingstad, T. F., and Gasol, J. M.: Bacterioplankton groups involved in the uptake of phosphate and dissolved organic phosphorus in a mesocosm experiment with P-starved Mediterranean waters, Environ. Microbiol., 14, 2334-2347, doi:10.1111/j.1462-2920.2012.02772.x, 2012.

Simon, M.: Specific uptake rates of amino acids by attached and free-living bacteria in a mesotrophic lake, Appl. Environ. Microb., 49, 1254-1259, 1985.

Talarmin, A., Van Wambeke, F., Catala, P., Courties, C., and Lebaron, P.: Flow cytometric assessment of specific leucine incorporation in the open Mediterranean, Biogeosciences, 8, 253265, doi:10.5194/bg-8-253-2011, 2011a.

Talarmin, A., Van Wambeke, F., Duhamel, S., Catala, P., Moutin, T., and Lebaron, P.: Improved methodology to measure taxonspecific phosphate uptake in live and unfiltered samples, Limnol. Oceanogr.-Meth., 9, 443-453, doi:10.4319/lom.2011.9.443, 2011b.

Tanaka, T., Rassoulzadegan, F., and Thingstad, T. F.: Measurements of phosphate affinity constants and phosphorus release rates from the microbial food web in Villefranche Bay, northwestern Mediterranean, Limnol. Oceanogr., 48, 1150-1160, 2003.

Tanaka, T., Thingstad, T. F., Christaki, U., Colombet, J., CornetBarthaux, V., Courties, C., Grattepanche, J.-D., Lagaria, A., Nedoma, J., Oriol, L., Psarra, S., Pujo-Pay, M., and Van Wambeke, F.: Lack of P-limitation of phytoplankton and heterotrophic prokaryotes in surface waters of three anticyclonic eddies in the stratified Mediterranean Sea, Biogeosciences, 8, 525-538, doi:10.5194/bg-8-525-2011, 2011
Ternon, E., Guieu, C., Ridame, C., L'Helguen, S., and Catala, P.: Longitudinal variability of the biogeochemical role of Mediterranean aerosols in the Mediterranean Sea, Biogeosciences, 8, 1067-1080, doi:10.5194/bg-8-1067-2011, 2011.

Thingstad, T. F., Skjoldal, E. F., and Bohne, R. A.: Phosphorus cycling and algal-bacterial competition in Sandsfjord, western Norway, Mar. Ecol. Prog. Ser., 99, 239-259, 1993.

Thingstad, T. F., Zweifel, U. L., and Rassoulzadegan, F.: P limitation of heterotrophic bacteria and phytoplankton in the northwest Mediterranean, Limnol. Oceanogr., 43, 88-94, 1998.

Webb, M. R.: A continuous spectrophotometric assay for inorganic phosphate and for measuring phosphate release kinetics in biological systems, P. Natl. Acad. Sci. USA, 89, 4884-4887, 1992.

Wu, J., Sunda, W., Boyle, E. A., and Karl, D. M.: Phosphate Depletion in the Western North Atlantic Ocean, Science, 289, 759-762, doi:10.1126/science.289.5480.759, 2000.

Zubkov, M. V., Mary, I., Woodward, E. M. S., Warwick, P. E., Fuchs, B. M., Scanlan, D. J., and Burkill, P. H.: Microbial control of phosphate in the nutrient-depleted North Atlantic subtropical gyre, Environ. Microbiol., 9, 2079-2089, 2007. 